\title{
Short communication: Relationships between a-lactalbumin and quality traits in bulk milk
}

\author{
E. Wickström, ${ }^{*}$ K. Persson Waller,†‡ H. Lindmark-Månsson,§ and Å. Sternesjö* \\ ${ }^{*}$ Department of Food Science and \\ †Department of Clinical Sciences, Swedish University of Agricultural Sciences, SE-750 07 Uppsala, Sweden \\ ‡Department of Animal Health and Antimicrobial Strategies, National Veterinary Institute, SE-751 89 Uppsala, Sweden \\ §Swedish Dairy Association, Ideon Science Park, SE-223 70 Lund, Sweden
}

\section{ABSTRACT}

The main objective of this study was to investigate whether the $\alpha$-lactalbumin ( $\alpha$-LA) content of bulk milk is related with some known inflammatory markers and milk quality traits. An additional objective was to study whether combining $\alpha$-LA, haptoglobin (Hp), and serum amyloid A (SAA) in an acute phase index (API) could be useful as an alternative marker for bulk milk quality. For the dairy industry, it is of great importance to receive high quality bulk milk for manufacture of liquid milk and dairy products. The somatic cell count (SCC) is currently used as an indirect marker for bulk milk quality, but because it is somewhat insensitive and unspecific, interest exists in alternative markers. Bulk milk samples were analyzed for $\alpha$-LA, SCC, polymorphonuclear leukocyte count, Hp, SAA, fat, lactose, total protein and casein contents, casein number, protein composition, proteolysis, and coagulating properties. No significant differences were found in SCC, polymorphonuclear leukocyte count, $\mathrm{Hp}$, or SAA between milk samples containing low, medium, or high concentrations of $\alpha$-LA. Differences between $\alpha$-LA groups were, however, found in some milk quality traits because high $\alpha$-LA concentration was related to low concentrations of $\alpha_{\mathrm{S1}^{-}}, \alpha_{\mathrm{S}^{-}}$, and $\beta$-caseins and high concentrations of lactose and $\beta$-lactoglobulin. A high API was related to low lactose content and casein number. Samples with high SCC contained less casein and had a lower casein number than milk with a low SCC, and proteolysis was significantly higher in high SCC milk than in low SCC milk. Neither $\alpha$-LA nor API proved to be a better marker than SCC for the quality traits investigated, and $\alpha$-LA was not considered to be a useful inflammatory marker in bulk milk.

Key words: bulk milk quality, somatic cell count, $\alpha$-lactalbumin, acute phase protein

Received October 28, 2009.

Accepted June 2, 2010.

${ }^{1}$ Corresponding author: ase.sternesjo@lmv.slu.se
All dairy processors depend on a continuous supply of high quality bulk milk from dairy producers. Mastitis, which is the most important disease in dairy cattle worldwide, leads to decreased milk production and impaired milk quality. The SCC is the most commonly used indicator of udder health and, indirectly, milk quality, although during recent years it has been criticized for being nonspecific and showing little correlation with bulk milk quality. There are many nonpathogenic factors that can influence SCC, such as stage of lactation and milking frequency (Harmon, 1994), and compositional changes (e.g., casein breakdown attributed to increased proteolytic activity in the udder) can persist even though SCC has returned to normal levels (Saeman et al., 1988). Recent studies have shown that the bovine acute phase proteins (APP) haptoglobin ( $\mathbf{H p})$ and serum amyloid A (SAA) might serve as alternative markers for bulk milk quality (Âkerstedt et al., 2009). Concentrations of these positive APP increase rapidly in milk during mastitis as a response to the initiation of inflammation (Eckersall et al., 2006).

During mastitis, levels of specific milk components (e.g., the whey protein $\alpha$-LA) are reduced. $\alpha$-Lactalbumin is one of 2 components making up lactose synthase, the enzyme regulating synthesis of lactose, which is the main osmoregulator of bovine milk (Farrell et al., 2004). Lactose content indirectly determines the volume of milk produced, and concentrations of $\alpha$-LA and lactose are strongly correlated (Kuhn et al., 1980). However, it is unclear whether milk production is affected by physiological variation in $\alpha$-LA and whether $\alpha-\mathrm{LA}$ is an important regulatory point of milk synthesis. Studies on different breeds and polymorphism of the $\alpha$-LA gene indicate, however, that increased expression of $\alpha$-LA is correlated with higher milk production (McFadden et al., 1989; Bleck and Bremel, 1993). Moreover, the concentration of $\alpha-\mathrm{LA}$ decreases during the course of lactation, and the concentration is higher in first-lactation cows compared with in older cows (Caffin et al., 1985).

In several studies, the milk $\alpha$-LA concentration has been shown to be influenced by mastitis (for a review, 
see Auldist and Hubble, 1998). Bortree et al. (1962) and Harmon et al. (1976) saw a decrease in $\alpha$-LA contents in udder quarters after experimentally induced mastitis, in conjunction with increased SCC. The decrease in $\alpha$-LA during mastitis is attributed to reduced synthesis and increased leakage between tight junctions in the mammary gland, and therefore, $\alpha$-LA has been suggested to serve as a marker for mammary function (Caffin et al., 1985). Hogarth et al. (2004) used a proteomic approach to identify new diagnostic markers for bovine mastitis. In agreement with previous studies mentioned above, a reduction in the $\alpha$-LA concentration in mastitic whey was observed. $\alpha$-Lactalbumin was suggested to be a negative APP in bovine milk because the concentration decreases as a consequence of the onset of the acute phase response. In humans, several negative APP have been identified, such as albumin, transferrin, and transthyretin (Ritchie et al., 1999). The idea of combining positive and negative APP in an index originates from human medicine (Ingenbleek and Young, 1994) and has also been evaluated in slaughtered animals to differentiate healthy from diseased animals (Toussaint et al., 1995). Such an index might also be useful and more specific than SCC as an indirect marker of milk quality, but this has never been evaluated.

To our knowledge, no studies have evaluated $\alpha$-LA as a marker of milk quality in relation to mastitis in bulk milk. Our objective was therefore to investigate whether $\alpha$-LA is related with some known inflammatory markers [i.e., SCC, polymorphonuclear leukocyte count (PMNC), Hp, and SAA] and with several milk quality traits (i.e., contents of total protein, casein, fat, and lactose, casein number, proteolysis, and rheological properties in bulk milk). We also wanted to study whether combining $\alpha-\mathrm{LA}, \mathrm{Hp}$, and SAA in an acute phase index (API) might be useful as an indirect marker for bulk milk quality, as previously proposed by others (Toussaint et al., 1995).

Bovine bulk milk samples from 91 farms were obtained in collaboration with the Milko dairy cooperative (Hedemora, Sweden). Determination of bulk-tank milk SCC was carried out using direct fluorescence-based cell counting (Fossomatic 5000, Foss, Hillerød, Denmark). The PMNC was determined by cell staining using direct, differential microscopy (Wickström et al., 2009). Haptoglobin was analyzed using an optical biosensor assay and SAA was determined using a commercial ELISA, both according to Åkerstedt et al. (2008). An API, defined as $[\mathrm{Hp}](\mathrm{mg} / \mathrm{L}) \times[\mathrm{SAA}](\mathrm{mg} / \mathrm{L}) /[\alpha-\mathrm{LA}]$ $(\mathrm{g} / \mathrm{L})$, was calculated for each sample. All values of $\mathrm{Hp}$ and SAA lower than the limit of detection were set to $0.3 \mathrm{mg} / \mathrm{L}$ (i.e., the detection limits of the assays). Total protein, fat, and lactose contents were measured using mid-infrared spectroscopy (Fourier Transform Instru- ment, FT 120, Foss). Casein content was determined by an indirect method ( $\AA$ kerstedt et al., 2008) and milk protein composition was analyzed using reverse-phase HPLC (Hallén et al., 2009). The extent of proteolysis was determined using a fluorescamine method (Wiking et al., 2002) and rheological properties were analyzed as described by Åkerstedt et al. (2008). To assess relationships between $\alpha$-LA and inflammatory markers and milk quality traits, and between API and milk quality traits, samples were categorized as below the 25 th percentile (low), between the 25 th and the 75 th percentile (medium), or above the 75 th percentile for $\alpha$-LA and API. Differences between the groups were analyzed with Student's $t$-test (version 15, Minitab Inc., State College, PA) for all factors, except for $\mathrm{Hp}$ and SAA in the case of $\alpha$-LA. For each of those 2 traits, milk samples were classified into 2 groups, below or above the limit of detection, and differences between $\alpha$-LA groups were analyzed using the chi-squared test. Somatic cell count, PMNC, API, and proteolysis were $\log$ transformed to obtain normal distribution of data, and statistical significance was defined as $P<0.05$.

No significant associations between levels of $\alpha$-LA and markers of inflammation were observed. Milk samples with different $\alpha$-LA concentrations did not differ significantly in numbers of SCC and PMNC (Table 1), although numerically lower numbers of cells were observed with increasing $\alpha$-LA content. This is in contrast to previous studies, reporting that the concentration of $\alpha$-LA is negatively correlated with mastitis and SCC (Bortree et al., 1962; Harmon et al., 1976; Auldist and Hubble, 1998). Most of the previous studies were, however, performed on quarter or cow composite milk rather than bulk milk and involved experimentally induced inflammation using pathogens such as Escherichia coli. Likewise, the $\alpha$-LA groups did not differ in numbers of samples with detectable concentrations of $\mathrm{Hp}\left(\chi^{2}\right.$ $=0.334,2 \mathrm{df}, P=0.84)$ or SAA $\left(\chi^{2}=0.052,2 \mathrm{df}, P\right.$ $=0.97$ ). Samples with detectable levels of Hp or SAA, however, had numerically higher concentrations of the APP with lower concentration of $\alpha$-LA (Table 1).

In contrast to the results for inflammatory markers, significant relationships were found between $\alpha$-LA and several bulk milk quality traits (i.e., lactose, $\beta$-LG, and $\alpha_{\mathrm{S1}^{-}}, \alpha_{\mathrm{S} 2^{-}}$, and $\beta$-CN; Table 2). Milk samples with low concentrations of $\alpha$-LA contained less lactose compared with samples in the high $\alpha$-LA group. On the contrary, contents of $\alpha_{\mathrm{S1}^{-}}, \alpha_{\mathrm{S}_{2}}$, and $\beta$-CN were highest in the low $\alpha$-LA group. Moreover, samples in the low $\alpha$-LA group had lower concentrations of $\beta$-LG than samples in the medium and high $\alpha$-LA groups. $\alpha$-Lactalbumin is one part of the enzyme lactose synthase and it is of major importance for lactose synthesis. Studies (Sarikaya et al., 2006; Bleck et al., 2009) have shown a strong as- 
Table 1. Inflammatory markers (mean $\pm \mathrm{SD}$ ) in bulk milk samples with low, medium, and high $\alpha$-LA concentrations

\begin{tabular}{lccc}
\hline & \multicolumn{3}{c}{$\alpha$-LA concentration ${ }^{2}$} \\
\cline { 2 - 4 } & $\begin{array}{c}\text { Low } \\
\text { Variable }\end{array}$ & $\begin{array}{c}\text { Medium } \\
(\mathrm{n}=45)\end{array}$ & $\begin{array}{c}\text { High } \\
(\mathrm{n}=23)\end{array}$ \\
\hline $\mathrm{\alpha}-\mathrm{LA}, \mathrm{g} / \mathrm{L}$ & $1.04 \pm 0.06^{\mathrm{a}}$ & $1.21 \pm 0.03^{\mathrm{b}}$ & $1.30 \pm 0.03^{\mathrm{c}}$ \\
$\mathrm{SCC}, \times 1,000$ cells/mL & $247.30 \pm 254.66$ & $188.51 \pm 133.81$ & $155.22 \pm 93.72$ \\
PMNC, $\times 1,000$ cells/mL & $80.51 \pm 96.01$ & $58.41 \pm 42.93$ & $43.90 \pm 50.12$ \\
Haptoglobin & $5(22)$ & $9(20)$ & $5(22)$ \\
Samples above LOD, n (\%) & $<0.3-4.70$ & $<0.3-2.10$ & $<0.3-0.78$ \\
Range, mg/L & $<0.3$ & $<0.3$ & $<0.3$ \\
Median, mg/L & & & $18(78)$ \\
Serum amyloid A & $17(74)$ & $33(73)$ & $<0.3-0.96$ \\
Samples above LOD, n (\%) & $<0.3-8.79$ & $<0.3-3.84$ & 0.59 \\
Range, mg/L & 0.88 & 0.59 & \\
Median, mg/L & &
\end{tabular}

${ }^{\mathrm{a}-\mathrm{c}}$ Means within a row with different superscripts differ $(P<0.05)$.

${ }^{1} \mathrm{PMNC}=$ polymorphonuclear leukocyte count; LOD $=$ limit of detection.

${ }^{2}$ Low: $<25$ th percentile of the sample values (range: $0.89-1.15 \mathrm{~g} / \mathrm{L}$ ); medium: 25 th to 75 th percentile of the sample values (range: $1.16-1.26 \mathrm{~g} / \mathrm{L}$ ); high: $>75$ th percentile of the sample values (range: $1.27-1.41 \mathrm{~g} / \mathrm{L}$ ).

sociation between $\alpha$-LA and lactose in bovine milk, but none have to our knowledge, like ours, been conducted on bulk milk. In the present study, a decline in $\beta$-LG concentration with decreasing $\alpha$-LA concentrations was also observed. This is in line with the report by Caffin et al. (1985) and is most likely explained by concurrent impaired cellular synthetic and secretory function. Caseins are the most important milk proteins for the dairy industry, making up the cheese curd. Milk with little or inferior casein will result in reduced cheese yield; therefore, affected milk implies a cost for dairy producers (Amenu and Deeth, 2007). In the present study we found that 3 of the investigated caseins (i.e., $\alpha_{\mathrm{S1}^{-}}, \alpha_{\mathrm{S}^{-}}$, and $\beta-\mathrm{CN}$, but not $\kappa-\mathrm{CN}$ ) decreased with increasing $\alpha$-LA concentration. This was unexpected because a high $\alpha$-LA concentration is considered to be an indicator of nonmastitic milk (Caffin et al., 1985; Auldist and Hubble, 1998). Milk with high $\alpha$-LA concentration could therefore be expected to have high casein content. In line with such an assumption, the $\mathrm{k}$ - $\mathrm{CN}$ concentration increased numerically, but not significantly, with increasing $\alpha-L A$ concentration. Relationships between $\alpha$-LA concentration and contents of total protein and casein supporting the data on the individual caseins were not found. Thus, the results regarding the individual proteins must be interpreted cautiously. In contrast, samples with high SCC contained less casein and had a lower casein number than milk with a low SCC (Table 2). Likewise, proteolysis was significantly higher in high SCC milk than in low SCC milk. It is, however, difficult to interpret whether the differences observed for proteolysis are of any significance in the dairy process.
When the bulk milk samples were divided into groups based on their API, intergroup differences were observed only for lactose content and casein number (Table 2). Samples with a low API had higher lactose content than the samples in the other groups, and the casein number increased with lower API. The inclusion of $\alpha-\mathrm{LA}$ in an API in combination with $\mathrm{Hp}$ and SAA did not result in a more sensitive marker for bulk milk quality than using Hp or SAA alone (Åkerstedt et al., 2009). The decrease in $\alpha$-LA during mastitis is probably of a much lower magnitude than the increase in $\mathrm{Hp}$ and SAA and therefore has little effect in an index.

In conclusion, $\alpha$-LA was not found to be a suitable marker of inflammation in bulk milk, but it was significantly related with several milk components, namely lactose, $\beta$-LG, and several individual caseins. The latter finding might not be of practical importance because $\alpha$-LA was not related to contents of total protein and casein. The proposed API consisting of $\alpha-\mathrm{LA}, \mathrm{Hp}$, and SAA was related to lactose content and casein number but was not considered to be a sensitive marker for bulk milk quality. Somatic cell count was related to several important quality traits (e.g., casein content, casein number, and proteolysis), although the practical significance of the latter may be questioned. In this study on bulk tank milk samples, neither $\alpha$-LA nor API proved to be a better marker than SCC for the quality traits investigated.

\section{ACKNOWLEDGMENTS}

The authors thank the Swedish Farmers' Foundation for Agricultural Research (Stockholm, Sweden) for 
Table 2. Milk quality traits (mean $\pm \mathrm{SD}$ ) in bulk milk samples with low, medium, and high $\alpha$-LA concentrations, acute phase indices (API), and total SCC

\begin{tabular}{|c|c|c|c|}
\hline Variable and investigated marker & Low & Medium & High \\
\hline \multicolumn{4}{|l|}{$\alpha$-LA concentrations ${ }^{1}$} \\
\hline Samples, n & 23 & 45 & 23 \\
\hline$\alpha-\mathrm{LA}, \mathrm{g} / \mathrm{L}$ & $1.04 \pm 0.06^{\mathrm{a}}$ & $1.21 \pm 0.03^{\mathrm{b}}$ & $1.30 \pm 0.03^{\mathrm{c}}$ \\
\hline Lactose, $\mathrm{g} / 100 \mathrm{~mL}$ & $4.57 \pm 0.10^{\mathrm{a}}$ & $4.62 \pm 0.10^{\mathrm{ab}}$ & $4.63 \pm 0.09^{\mathrm{b}}$ \\
\hline$\alpha_{\mathrm{S}^{-}}-\mathrm{CN}, \mathrm{g} / \mathrm{L}$ & $9.42 \pm 1.24^{\mathrm{a}}$ & $9.45 \pm 1.48^{\mathrm{a}}$ & $9.16 \pm 0.80^{\mathrm{b}}$ \\
\hline$\alpha_{\mathrm{S} 2}-\mathrm{CN}, \mathrm{g} / \mathrm{L}$ & $3.62 \pm 0.71^{\mathrm{a}}$ & $3.63 \pm 0.72^{\mathrm{ab}}$ & $3.55 \pm 0.93^{\mathrm{b}}$ \\
\hline$\beta-\mathrm{CN}, \mathrm{g} / \mathrm{L}$ & $16.14 \pm 1.87^{\mathrm{a}}$ & $16.09 \pm 2.93^{\mathrm{ab}}$ & $15.73 \pm 1.85^{\mathrm{b}}$ \\
\hline$\beta-L G, g / L$ & $4.24 \pm 0.25^{\mathrm{a}}$ & $4.29 \pm 0.43^{\mathrm{b}}$ & $4.29 \pm 0.23^{\mathrm{b}}$ \\
\hline \multicolumn{4}{|l|}{$\mathrm{API}^{2}$} \\
\hline Samples, $\mathrm{n}$ & 23 & 45 & 23 \\
\hline $\mathrm{API}^{3}$ & $0.07 \pm 0.01^{\mathrm{a}}$ & $0.17 \pm 0.06^{\mathrm{b}}$ & $2.86 \pm 8.56^{\mathrm{c}}$ \\
\hline Lactose, $\mathrm{g} / 100 \mathrm{~mL}$ & $4.70 \pm 0.07^{\mathrm{a}}$ & $4.59 \pm 0.10^{\mathrm{b}}$ & $4.56 \pm 0.10^{\mathrm{b}}$ \\
\hline Casein number & $73.32 \pm 0.68^{\mathrm{a}}$ & $72.96 \pm 0.65^{\mathrm{b}}$ & $72.56 \pm 0.51^{\mathrm{c}}$ \\
\hline$\alpha-\mathrm{LA}, \mathrm{g} / \mathrm{L}$ & $1.23 \pm 0.07^{\mathrm{a}}$ & $1.18 \pm 0.11^{\mathrm{b}}$ & $1.18 \pm 0.12^{\mathrm{ab}}$ \\
\hline \multicolumn{4}{|l|}{ Total SCC ${ }^{4}$} \\
\hline Samples, $\mathrm{n}$ & 23 & 45 & 23 \\
\hline $\mathrm{SCC}, \times 1,000$ cells $/ \mathrm{mL}$ & $74.70 \pm 22.40^{\mathrm{a}}$ & $155.60 \pm 31.25^{\mathrm{b}}$ & $392.22 \pm 237.10^{\mathrm{c}}$ \\
\hline PMNC ${ }^{5} \times 1,000$ cells $/ \mathrm{mL}$ & $16.66 \pm 8.27^{\mathrm{a}}$ & $45.33 \pm 17.85^{\mathrm{b}}$ & $133.35 \pm 84.80^{\mathrm{c}}$ \\
\hline $\mathrm{PMN}^{6} \%$ of SCC & $21.6 \pm 6.8^{\mathrm{a}}$ & $28.5 \pm 6.6^{\mathrm{b}}$ & $33.6 \pm 7.4^{\mathrm{c}}$ \\
\hline Fat, $\mathrm{g} / 100 \mathrm{~mL}$ & $4.68 \pm 0.47^{\mathrm{a}}$ & $4.39 \pm 0.44^{\mathrm{b}}$ & $4.47 \pm 0.28^{\mathrm{ab}}$ \\
\hline Lactose, $\mathrm{g} / 100 \mathrm{~mL}$ & $4.65 \pm 0.13^{\mathrm{a}}$ & $4.61 \pm 0.10^{\mathrm{ab}}$ & $4.57 \pm 0.08^{\mathrm{b}}$ \\
\hline Casein content, $\mathrm{g} / 100 \mathrm{~mL}$ & $2.63 \pm 0.16^{\mathrm{a}}$ & $2.58 \pm 0.13^{\mathrm{ab}}$ & $2.54 \pm 0.11^{\mathrm{b}}$ \\
\hline Casein number & $73.17 \pm 0.69^{\mathrm{a}}$ & $73.06 \pm 0.56^{\mathrm{b}}$ & $72.51 \pm 0.70^{\mathrm{b}}$ \\
\hline Proteolysis, $\mathrm{m} M$ & $1.03 \pm 0.06^{\mathrm{a}}$ & $1.07 \pm 0.06^{\mathrm{ab}}$ & $1.08 \pm 0.07^{\mathrm{b}}$ \\
\hline
\end{tabular}

${ }^{\mathrm{a}-\mathrm{c}}$ Means within a row with different superscripts differ $(P<0.05)$.

${ }^{1}$ Low: $<25$ th percentile of the sample values $(\alpha-\mathrm{LA}$ range: $0.89-1.15 \mathrm{~g} / \mathrm{L}$ ); medium: 25 th to 75 th percentile of the sample values ( $\alpha$-LA range: 1.16-1.26 g/L); high: $>75$ th percentile of the sample values ( $\alpha$-LA range: $1.27-1.41 \mathrm{~g} / \mathrm{L})$.

${ }^{2}$ Low: $<25$ th percentile of the sample values (API range: 0.07-0.09); medium: 25 th to 75 th percentile of the sample values (API range: $0.10-0.32$ ); high: $>75$ th percentile of the sample values (API range: $0.33-41.84$ ).

${ }^{3}$ All values of haptoglobin and serum amyloid A lower than the limit of detection were set to $0.3 \mathrm{mg} / \mathrm{L}$ (i.e., the detection limit of the assays). The proportions of samples above the limit of detection $(0.3 \mathrm{mg} / \mathrm{L})$ were 0, 9, and $74 \%$ for haptoglobin and 26, 89 , and $100 \%$ for serum amyloid A in the low, medium, and high API groups, respectively.

${ }^{4}$ Low: $<25$ th percentile of the sample values (SCC range: $33-104 \times 1,000$ cells $/ \mathrm{mL}$ ); medium: 25 th to 75 th percentile of the sample values (SCC range: $105-221 \times 1,000$ cells $/ \mathrm{mL}$ ); high: $>75$ th percentile of the sample values (SCC range: $222-1,397 \times 1,000$ cells $/ \mathrm{mL}$ ).

${ }^{5} \mathrm{PMNC}=$ polymorphonuclear leukocyte count.

${ }^{6} \mathrm{PMN}=$ polymorphonuclear leukocyte.

funding the project. The farmers and tanker drivers of the Milko Dairy Company (Hedemora, Sweden) are acknowledged for their cooperation. The support from Maria Åkerstedt, Malin Thors, and Lotta Wall at the Department of Food Science, Swedish University of Agricultural Sciences (Uppsala, Sweden), in collecting and analyzing milk samples is appreciated.

\section{REFERENCES}

Åkerstedt, M., K. Persson Waller, L. B. Larsen, L. Forsbäck, and A. Sternesjö. 2008. Relationship between haptoglobin and serum amyloid A in milk and milk quality. Int. Dairy J. 18:669-674.

Åkerstedt, M., K. Persson Waller, and Å. Sternesjö. 2009. Haptoglobin and serum amyloid A in bulk tank milk in relation to raw milk quality. J. Dairy Res. 76:483-489.
Amenu, B., and H. C. Deeth. 2007. The impact of milk composition on cheddar cheese manufacture. Aust. J. Dairy Technol. 62:171184.

Auldist, M. J., and I. B. Hubble. 1998. Effects of mastitis on raw milk and dairy products. Aust. J. Dairy Technol. 53:28-36.

Bleck, G. T., and R. D. Bremel. 1993. Correlation of the alpha-lactalbumin $(+15)$ polymorphism to milk production and milk composition of Holsteins. J. Dairy Sci. 76:2292-2298.

Bleck, G. T., M. B. Wheeler, L. B. Hansen, H. Chester-Jones, and D. J. Miller. 2009. Lactose synthase components in milk: Concentrations of $\alpha$-lactalbumin and $\beta 1$,4-galactosyltransferase in milk of cows from several breeds at various stages of lactation. Reprod. Domest. Anim. 44:241-247.

Bortree, A. L., E. J. Carroll, and O. W. Schalm. 1962. Whey protein patterns of milk from cows with experimentally produced mastitis. J. Dairy Sci. 45:1465-1471.

Caffin, J. P., B. Poutrel, and P. Rainard. 1985. Physiological and pathological factors influencing bovine $\alpha$-lactalbumin and $\beta$-lactoglobulin concentrations in milk. J. Dairy Sci. 68:1087-1094. 
Eckersall, P. D., F. J. Young, A. M. Nolan, C. H. Knight, C. McComb, M. H. Waterson, C. J. Hogarth, E. M. Scott, and J. L. Fitzpatrick. 2006. Acute phase proteins in bovine milk in an experimental model of Staphylococcus aureus subclinical mastitis. J. Dairy Sci. 89:1488-1501.

Farrell, H. M. Jr, R. Jimenez-Flores, G. T. Bleck, E. M. Brown, J. E. Butler, L. K. Creamer, C. L. Hicks, C. M. Hollar, K. F. Ng-KawiHang, and H. E. Swaisgood. 2004. Nomenclature of the proteins of cow's milk - Sixth revision. J. Dairy Sci. 87:1641-1674.

Hallén, E., T. Allmere, A. Lundén, and A. Andrén. 2009. Effect of genetic polymorphism of milk proteins on rheology of acid-induced milk gels. Int. Dairy J. 19:399-404.

Harmon, R. J. 1994. Symposium: Mastitis and genetic evaluation for somatic cell count: Physiology of mastitis and factors affecting somatic cell counts. J. Dairy Sci. 77:2103-2112.

Harmon, R. J., F. L. Schanbacher, L. C. Ferguson, and K. L. Smith. 1976. Changes in lactoferrin, immunoglobulin G, bovine serum albumin and $\alpha$-lactalbumin during acute experimental and natural coliform mastitis in cows. Infect. Immun. 13:533-542.

Hogarth, C. J., J. L. Fitzpatrick, A. M. Nolan, F. J. Young, A. Pitt, and P. D. Eckersall. 2004. Differential protein composition of bovine whey: A comparison of whey from healthy animals and from those with clinical mastitis. Proteomics 4:2094-2100.

Ingenbleek, Y., and V. Young. 1994. Transthyretin (prealbumin) in health and disease: Nutritional implications. Annu. Rev. Nutr. 14:495-533.

Kuhn, N. J., D. T. Carrick, and C. J. Wilde. 1980. Lactose synthase: The possibilities of regulation. J. Dairy Sci. 63:328-336.
McFadden, T. B., R. M. Akers, and W. E. Beal. 1989. Influence of breed and hormones on production of milk proteins by mammary explants from prepubertal heifers. J. Dairy Sci. 72:1754-1763.

Ritchie, R. F., G. E. Palomaki, L. M. Neveux, O. Navolotskaia, T. B. Ledue, and W. Y. Craig. 1999. Reference distributions for the negative acute-phase serum proteins, albumin, transferrin and transthyretin: A practical, simple and clinically relevant approach in a large cohort. J. Clin. Lab. Anal. 13:273-279.

Saeman, A. I., R. J. Verdi, D. M. Galton, and D. M. Barbano. 1988. Effect of mastitis on proteolytic activity in bovine milk. J. Dairy Sci. 71:505-512.

Sarikaya, H., G. Schlamberger, H. H. D. Meyer, and R. M. Bruckmaier. 2006. Leukocyte populations and mRNA expression of inflammatory factors in quarter milk fractions at different somatic cell score levels in dairy cows. J. Dairy Sci. 89:2479-2486.

Toussaint, M. J. M., A. M. van Ederen, and E. Gruys. 1995. Implication of clinical pathology in assessment of animal health and in animal production and meat inspection. Comp. Haematol. Int. 5:149-157.

Wickström, E., K. Persson Waller, K. Östensson, H. Lindmark-Månsson, and Å. Sternesjö. 2009. Relationships between somatic cell count, polymorphonuclear leukocyte count and milk quality traits in bulk tank milk. J. Dairy Res. 76:195-201.

Wiking, L., M. B. Frost, L. B. Larsen, and J. H. Nielsen. 2002. Effects of storage conditions on lipolysis, proteolysis and sensory attributes in high quality raw milk. Milchwissenschaft 59:190-194. 